\title{
Do omnivorous shrimp influence mayfly nymph life history traits in a tropical island stream?
}

\author{
Nicholas A. Macías ${ }^{1,2}$, Checo Colón-Gaud ${ }^{2}$, Jonathan W. Duggins ${ }^{2,3}$ \& Alonso Ramírez ${ }^{4}$ \\ 1. California State University - Sacramento, Biological Sciences, Sacramento, CA 95819, USA; \\ nm01510@georgiasouthern.edu \\ 2. Georgia Southern University, Biology Department, Statesboro, GA 30460, USA; jccolongaud@georgiasouthern.edu \\ 3. University of North Carolina Wilmington, Department of Mathematics and Statistics, Wilmington, NC 28403, USA; \\ dugginsj@uncw.edu \\ 4. Deparment of Environmental Sciences, University of Puerto Rico, Rio Piedras Campus, San Juan, PR 00931, USA; \\ aramirez@ramirezlab.net
}

Received 12-XII-2013. C Corrected 20-I-2014. Accepted 13-II-2014.

\begin{abstract}
Interspecific interactions can play an important role in determining habitat selection and resource use between competing species. We examined interactions between an omnivorous shrimp and a grazing mayfly, two co-dominant taxa found in Puerto Rican headwater streams, to assess how predator presence may influence mayfly resource use and instantaneous growth in a tropical rainforest ecosystem. We conducted a series of behavioral and growth experiments to determine the effects of the freshwater shrimp, Xiphocaris elongata, on the growth rate and resource selection of mayfly nymphs in the family Leptophlebiidae. For resource choice assessments, we conducted a series of five day laboratory experiments where mayflies were given access to two resource substrate choices (cobble vs. leaves) in the presence or absence of shrimp. To assess for the effects of shrimp on mayfly fitness, we measured mayfly growth in laboratory aquaria after five days using four treatments (cobble, leaves, cobble + leaves, no resource) in the presence or absence of shrimp. In resource choice experiments, mayflies showed preference for cobble over leaf substrata $(\mathrm{p}<0.05)$ regardless of the presence of shrimps, however, the preference for cobble was significantly greater when shrimp were present in the leaf habitat. In growth experiments, there were no statistical differences in mayfly growth in the presence or absence of shrimp $(\mathrm{p}=0.07)$. However, we measured increased mayfly nymph growth in the absence of predators and when both cobble and leaves were available. Our results suggest that interspecific interactions between these taxa could potentially influence organic matter resource dynamics (e.g., leaf litter processing and export) in Puerto Rican streams. Rev. Biol. Trop. 62 (Suppl. 2): 41-51. Epub 2014 April 01.
\end{abstract}

Key words: interspecific interactions, predator-prey, shrimp, mayflies, tropical streams.

Predator-prey interactions can be complex and can modify abundance, behavior, habitat utilization, and competition for both predator and prey (Posey \& Hines, 1991; Persson, Andersson, Baden \& Moksnes, 2008). Predator-prey interactions can also influence prey life history and drive habitat selection within available niche space to avoid mortality (Rosenzweig, 1981; Connell, 1983; Peckarsky, Taylor, McIntosh, McPeek \& Lytle, 2001). Upland streams in the island of Puerto Rico's Luquillo Experimental Forest (LEF) provide an ideal ecosystem for examining the influence of interspecific interactions as they generally include few trophic levels with a small number of dominant consumers (Covich \& McDowell, 1996). In these ecosystems, freshwater shrimps can play an important role as they occupy several trophic compartments (e.g., predators, omnivores, shredders, filterers, grazers) and can be the top consumers in the absence of predatory fishes (Covich, Crowl, Hein, Townsend $\&$ McDowell, 2009). In addition, shrimps make up most of the overall biomass of total stream 
organisms at the LEF (Covich, Crowl, Johnson, Varza \& Certain, 1991; Covich, Crowl, Johnson \& Pyron, 1996; Crowl, McDowell, Covich \& Johnson, 2001). Shrimps can have a significant influence on ecosystem function through regulating leaf litter breakdown and sediment concentration and deposition (Pringle, Blake, Covich, Buzby \& Finley, 1993; Crowl, Welsh, Heartsill-Scalley \& Covich, 2006; Bobeldyk \& Ramírez, 2007; Cross, Covich, Crowl, Benstead \& Ramirez, 2008).

Shrimp assemblages in LEF streams include up to ten different species within three families (Atyidae, Xiphocarididae, Palaemonidae). However, over $90 \%$ of the assemblage is generally dominated by two taxa, Xiphocaris elongata and Atya lanipes, with lower numbers of all other taxa. Although each taxon has developed specialized feeding behaviors and resource preferences, both are known to influence aquatic insect assemblages either directly through predation or indirectly through competition or facilitation (Pringle et al., 1993). In LEF streams, X. elongata, has been described as an omnivore and feeds on animal material, periphyton, leaf litter and suspended particulates (Crowl, Bouwes, Townsend, Covich \& Scatena, 2000; Crowl et al., 2001; Cross et al., 2008).

Leptophlebiid mayflies are one of the most abundant aquatic insects in the higher elevation streams of the LEF (Pescador, Masteller \& Buzby, 1993; Crowl et al., 2000). As nymphs, many mayfly taxa are grazers that prefer feeding on periphyton on the top of substrata during night hours (Culp, Glozier \& Scrimgeour, 1991; Cowan \& Peckarsky, 1994; McIntosh, Peckarsky \& Taylor, 1999). This feeding behavior has been correlated to optimal fitness and fecundity (Scrimgeour \& Culp, 1994). The top surface of substrata supports high periphyton availability and high risk of predation, while the bottom surface supports low periphyton availability and low predation risk (Scrimgeour \& Culp, 1994). Thus, the preferred foraging habits of mayflies, on the top of substrata, leave them most susceptible to predation (Kohler \& McPeek, 1989; Culp \&
Scrimgeour, 1993; Scrimgeour \& Culp, 1994). Previous studies at LEF streams suggest that leptophlebiid mayflies can contribute appreciably to shrimp diets due to their high abundance relative to other available animal food items (Crowl et al., 2000; Cross et al., 2008). Furthermore, $X$. elongata may not only influence mayfly assemblages directly through predation, but can also serve as a competitor for autochthonous resources.

The purpose of this study was to assess the physical and behavioral responses of leptophlebiid mayflies in close proximity to $X$. elongata . We predicted that foraging leptophlebiids will trade-off from the benefits of food ingestion against the costs of mortality risk due to predation. This risk should trigger a shift from an optimal resource (e.g., periphyton growing on cobble) to a lower quality alternative (e.g., detritus) (Kohler \& McPeek, 1989; Scrimgeour \& Culp, 1994). Our overall goal was to gain a better understanding of the interactions between two dominant organisms in this tropical island stream ecosystem. We achieved this by assessing the response of leptophlebiids using fitness variables (i.e., growth rate and foraging behavior) as a proxy for overall organism success in an ex-situ microcosm experiment.

\section{MATERIALS AND METHODS}

Study site: Experiments were conducted at the El Verde Field Station (hereafter, El Verde) in northeastern Puerto Rico. The field station is part of the Luquillo Experimental Forest (LEF), a site of the National Science Foundation's Long Term Ecological Research Network (i.e., LUQ LTER). The LEF is also known as the El Yunque National Forest (formerly the Caribbean National Forest) and is administered by the U.S.D.A Forest Service. This tropical wet forest receives an average of $350 \mathrm{~cm}$ of precipitation per year with peaks from May to December. Water temperatures range from 18 to $26^{\circ} \mathrm{C}$ (mean $22^{\circ} \mathrm{C}$ ) at 200-600m in elevation. Riparian habitats are heavily forested and dominated by Dacryodes excelsa (tabonuco) and Prestoea montana 
(sierra palm). Leaf fall is continuous throughout the year and often peaks during the drier part of the year, with the highest rates occurring from April to June. Stream-bottom substrata are dominated by large boulders and cobble in erosional (i.e., riffles) habitats and by fine sediments at shallow, depositional (i.e., pools) habitats. The stream food webs at El Verde are thought to be primarily detritus based with relatively few trophic linkages compared to most mainland streams. Shrimps represent the dominant consumer group (Covich \& McDowell, 1996).

Consumer and resource collections: In June 2010, leptophlebiid mayfly nymphs $(<5 \mathrm{~mm}$ in length) and small individuals ( $\sim 30$ $40 \mathrm{~mm}$ ) of the freshwater shrimp Xiphocaris elongata (Decapoda: Xiphocarididae) were collected from tributaries of headwater streams near El Verde and kept in aerated containers in the laboratory. Mayflies in the family Leptophlebiidae are represented by 4-5 different species in streams at El Verde, with Neohagenulus as the most commonly found genus ( $\sim 90 \%$ of leptophlebiids; Pescador et al., 1993). At the same time as consumer collections, leaves of common riparian trees and small cobbles $(<150 \mathrm{~mm}$ in diameter) were collected from the stream channel, washed and scrubbed of any macroinvertebrates, current algal growth, and fine sediment (e.g., sand, silt) and retained for later use as resource substrata in experimental trials. To allow for resource conditioning (i.e., initial leaching/fragmentation, microbial colonization, and periphyton growth) individual cobbles and leaves were placed in open canopy stream-side channels for $6-8 d$ at El Verde (see Cross et al., 2008 for further details on stream-side channels). To control for consumptive losses during the conditioning period, resources were placed in free flowing cages that excluded consumers, but maintained materials submerged.

Mayfly resource preference: We conducted a series of behavioral observation trials in laboratory microcosms filled with stream water to assess the effects of shrimp on mayfly resource selection (i.e., preference). Microcosms were $4.30 \mathrm{~L}$ and divided into two equally-sized chambers using $3 \mathrm{~mm}$ plastic mesh. Resources were positioned in each side chamber (Fig. 1A) to represent the major food item and habitat
A

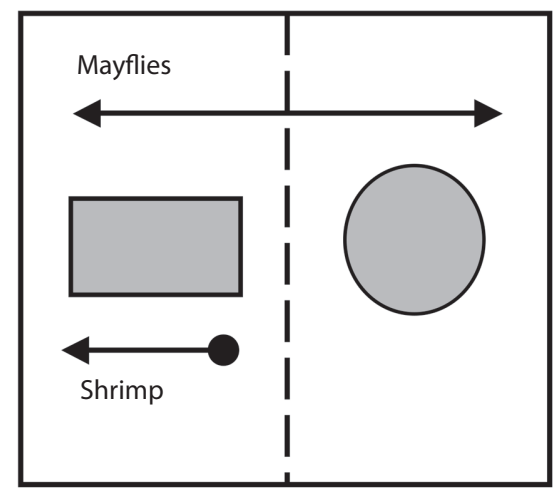

B

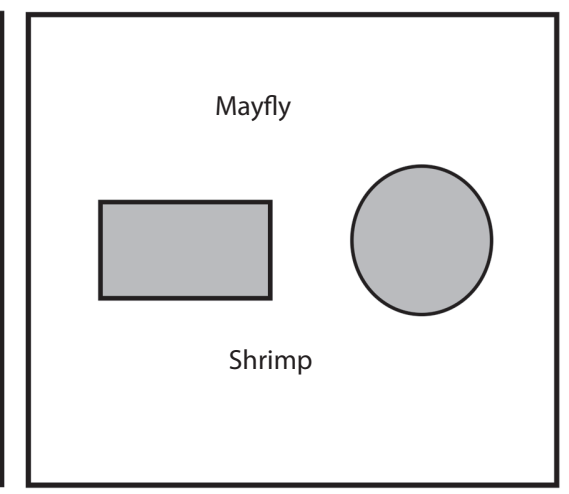

Fig. 1. Simplified diagrams of individual microcosms for: (A) resource preference experiments and (B) mayfly growth experiments. Larger boxes represent the overall size and shape of aquaria $(4.3 \mathrm{~L}$ for behavioral experiments and $739 \mathrm{~mL}$ for growth experiments). Smaller, gray shapes inside larger aquaria represent the different substrate resource treatments (e.g., gray rectangles=leaves; gray circles=cobbles). For the resource preference experiment (A, left side), an example for predator on the leaf side of microcosm is being portrayed. Dashed line intersecting the microcosm represents the mesh screening to prevent shrimp access to both sides of aquaria. Arrows represent the potential movement of consumers in the microcosms. For the growth experiment (B, right side), an example for both resources with predator treatment is being portrayed. 
where these consumers were found feeding (e.g., scraping/grazing). Cobbles and tabonuco leaves collected from streams nearby El Verde were used as substrata and processed as described above (see Consumer and resource collections). Each substrate alternative may not necessarily represent a different resource base (i.e., biofilms, periphyton), but they are substantially different habitats for this small consumer.

Two sets of trial runs, each lasting five days, and using a total of 15 microcosms representing three treatments (five with shrimp in leaf side, five with shrimp in cobble side, five with no shrimp) were conducted for the trial $(n=30)$. Prior to the beginning of the trial, 10-20 mayfly nymphs were placed into each microcosm and allowed to acclimate for $\sim 15 \mathrm{~min}$. After this time, an individual shrimp was placed in a predetermined substrate side of the microcosm to represent all treatments. Assignment of study treatments based on shrimp placement in the microcosm (leaf-side vs. cobble-side) was determined at random to include five replicates of each treatment per trial run. During the trial period, two observations were made during each day of the trial period, one observation during the day and one at night ( $\sim 5-10 \mathrm{~min}$ per microcosm). Night time observations were made using red light to account for differences in activity of the consumers. During each observation period, all visible mayfly nymphs on each side chamber, including individuals on top of substrata as well as those visible in the corners of the microcosms, were recorded. At the end of each trial period, a plastic barrier was placed between resources to prohibit movement and the total number of individual mayflies present on either side was recorded.

Mayfly growth rates: To assess for the effects of shrimps on mayfly success and overall fitness, we conducted a series of growth experiments in 72 microcosms $(739 \mathrm{~mL}$ aquaria). Mayfly growth was measured in the presence or absence of shrimp in three resource/ substrate treatments (e.g., leaf detritus, cobble [i.e., as a surface for periphyton growth], leaves and cobble combined) and one no-resource treatment. Mayfly nymphs and shrimp were collected and retained until trials as described above (see Consumer and resource collections). Post-abscission leaves of yagrumo (Cecropia schreberiana) were collected from the forest floor at El Verde and kept at room temperature until further processing. Small stones (cobbles $\sim 64-138 \mathrm{~mm}$ in diameter) were collected from the stream channel at headwater reaches of El Verde. Individual leaves were cut into strips and weighed to $\sim 0.5 \mathrm{~g}$. Leaves and cobbles were rinsed and scrubbed of any sediments and organisms and conditioned as previously described (see Consumer and resource collections). After conditioning, leaf strips and cobbles were transported to the laboratory for trials and placed in the experimental microcosms.

Individual mayflies and shrimp were measured to the nearest $\mathrm{mm}$ using gridded paper and a dissecting microscope. Each trial consisted of a 1:1:1 of consumers to resources (e.g., 1 mayfly, 1 shrimp, 1 leaf/cobble), except for shrimp absence trials (1:0:1), resource combination trials (leaves and periphyton, 1:1:2 or $1: 0: 2)$, and no-resource trials $(1: 1: 0$ or $1: 0: 0)$ (Fig. 1B). Trials lasted a total of five days. After each trial, individual mayflies were removed from microcosms and re-measured to the nearest $\mathrm{mm}$ to estimate individual daily growth. Published length-mass relationships (Benke, Huryn, Smock \& Wallace, 1999) were used to correct length measurements for individual mass. We based our estimates on length-mass relationships for the mayfly nymph Habrophlebia vibrans (North Carolina, USA) as it most closely represented the size range of the leptophlebiid mayfly nymphs from these study sites. Individual daily growth was estimated by the instantaneous growth method (Benke \& Huryn, 2006) as amount of weight gained based on the following equation:

$$
g=\frac{\ln \left(W_{t}+\Delta t / W_{t}\right)}{\Delta t}
$$

Where $W_{t}$ indicates the weight estimate at the beginning of the trial and $W_{t+\Delta t}$ indicates the 
weight estimate at the end of the trial. Individual mayflies that failed to survive the entire duration of the trial were removed and accounted for mortality estimates. Individual shrimps that failed to survive or escaped the container were replaced as soon as noticed and the trial continued. After trials and measurements mayfly nymphs were preserved in $\sim 10 \%$ ethanol and individual shrimps were returned to the streams where they were obtained.

\section{Statistical analysis}

Mayfly resource preference: To determine whether a preference for a certain resource was present a generalized estimating equation (GEE) was fit to the proportion of mayflies that chose the cobble substrate. The decision to use the cobble instead of the tabonuco leaf substrate is arbitrary as there are only the two groups making the responses (i.e., proportions) perfectly dependent. The use of GEE was based on two factors: the responses are highly nonnormal requiring a generalized linear model and the possibility of some correlation between the repeated uses of the same microcosm (i.e., aquarium) in successive trials required a repeated measures analysis.

We used SAS version 9.2 (SAS Institute, Cary, NC, USA) to investigate combinations of distributions, link functions, and correlations structures in choosing the final GEE. The decision regarding optimality was based on the quasi-likelihood criterion (Pan, 2001) and resulted in the selection of a binomial distribution with the canonical logit link. The working correlation matrix was best estimated by selecting an exchangeable structure (i.e., compound-symmetry). In addition to assessing the coefficient estimates from this model, contrasts were investigated using the chi-square test provided in SAS version 9.2 in order to directly compare the treatment effects arising from introducing the predator with the leaf, with the cobble, or not introducing the predator at all.

Mayfly growth rates: We analyzed growth rates by way of an ANOVA using the presence/absence of predator and type of substrate (leaf, cobble, leaf and cobble) as factors in SAS version 9.2. Prior to statistical analyses, all 18 estimates obtained from the no-resource treatments (e.g., nine with predator and nine without predator) were removed as these resulted in mortality (thus zero growth) in $100 \%$ of the replicates. Based on observations of the 18 no-resource treatments, mortality in nine of the interactions was predicted to be the result of direct predation by the shrimp. An interaction was initially included to ascertain whether or not the tests for effects on growth rates due to predator and/or substrate were interpretable. Based on the data collected the presence of an interaction was not supported $(\mathrm{F}=0.21$, d.f. $=2$, $\mathrm{p}=0.81$ ) and was removed, leaving an additive model for all subsequent analyses. Any necessary follow-up analysis was based on analysis of the least-squares means because the experiment was slightly unbalanced.

\section{RESULTS}

Mayfly resource preference: The overall distribution of mayfly nymphs repeatedly favored the cobble substrate side of the experimental microcosms throughout the study (Fig. 2). As many as $72 \%$ (cobble+shrimp) and up to $95 \%$ (leaf+shrimp) of the mayfly nymphs showed preference for the cobble resource/ substrate regardless of treatment (i.e., shrimp placement). Based on the contrasts from the resulting model we found that there was no substantial difference in mayfly nymph distribution between not introducing the predator (e.g., no shrimp) and introducing the predator in the cobble substrate side $(\mathrm{p}=0.50)$. However, both remaining comparisons show significant differences in mayfly distribution (i.e., resource preference) between the leaf-side vs. cobbleside with predator $(\mathrm{p}=0.04)$ and between the leaf-side with predator vs. no predator $(\mathrm{p}=0.02)$ as shown in Table 1.

Mayfly growth rates: Mayfly growth rates ranged from $0.02 \pm 0.01$ to $0.07 \pm 0.02$ (mean $\mathrm{mg}$ per day $\pm \mathrm{SE}$ ) with some of the 


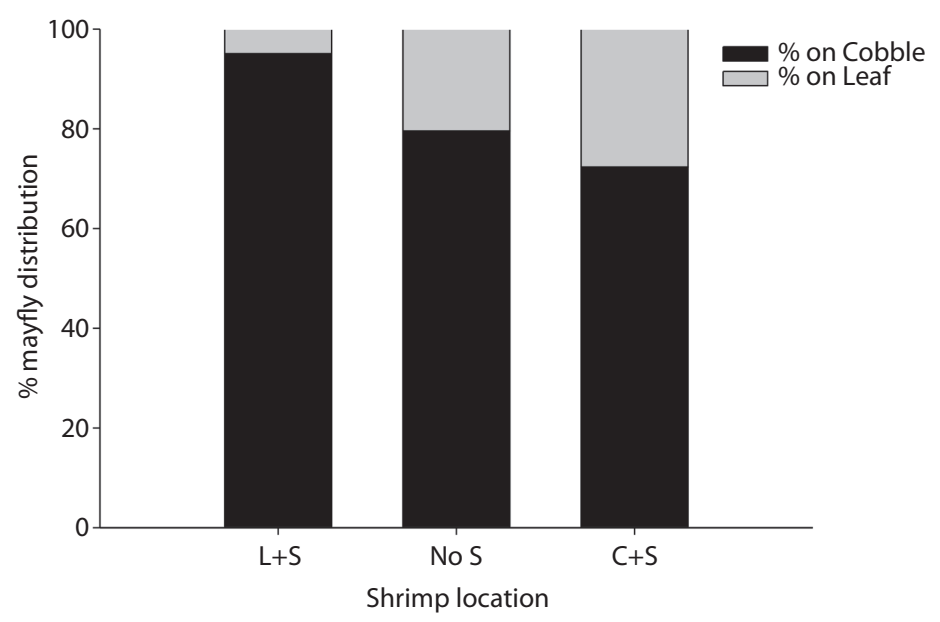

Fig. 2. Percent distribution of Leptophlebiidae mayflies by resource ( $\%$ Cobble=black bars; \% Leaf=gray bars) in relation to positioning of omnivorous shrimp (X. elongata) by treatment $(\mathrm{L}+\mathrm{S}=$ shrimp in leaf side; No $\mathrm{S}=$ no shrimp (Control); $\mathrm{C}+\mathrm{S}=$ shrimp in cobble side).

TABLE 1

Contrast results from generalized estimating equation (GEE) analysis for resource preference experiments. Different treatments indicate the location of shrimp predator $(\mathrm{L}+\mathrm{S}=$ shrimp in leaf side; No $\mathrm{S}=$ no shrimp control; $\mathrm{C}+\mathrm{S}=$ shrimp in cobble side). A Chi-square $\left(X^{2}\right)$ test was used to compare the treatment effects.

\begin{tabular}{lccc}
\multicolumn{1}{c}{ Treatment (Contrast) } & d.f. & $X^{2}$ & $p$ value \\
L + S (One) & 1 & 5.71 & 0.02 \\
No S (Two) & 1 & 4.21 & 0.04 \\
C + S (Three) & 1 & 0.46 & 0.50 \\
\hline
\end{tabular}

higher growth estimates found in the absence of the predator and when both resource substrates (leaf+cobble) were present (Fig. 3). Prior to the removal of the interaction term, mayfly growth rates in neither substrate $(\mathrm{p}=0.21)$ nor predator $(\mathrm{p}=0.08)$ treatment were considered significantly different as shown in Table 2. After removing the interaction from the model, both factors remained insignificant, though p-values did decrease slightly. Growth rates in different substrate treatments had $\mathrm{p}=0.20$ and growth rates compared across predator treatments had a $\mathrm{p}=0.07$. The complete results are provided in Table 3.

\section{DISCUSSION}

Overall, our results suggest that leptophlebiid mayflies preferred cobble substrata regardless of the presence of the shrimp predator. Cobble in these streams can serve as suitable attachment structures for different forms of benthic algae that can be exploited by mayfly grazers. However, these substrata may also offer a more complex structure for shelter and predator avoidance. Leptophlebiid mayflies are dorsoventrally flattened in body shape thus allowing them to move over the surface of cobble (e.g., crawling) as well as to swim from surface to surface. Moreover, our results indicated that when $X$. elongata is present in the side with the leaf resource, leptophlebiid mayflies distribution would almost completely shift towards the cobble side (without the predator). Leptophlebiid mayflies showed an even stronger preference for the cobble resource, as compared to, the presence of the predator with the cobble resource or having the predator 


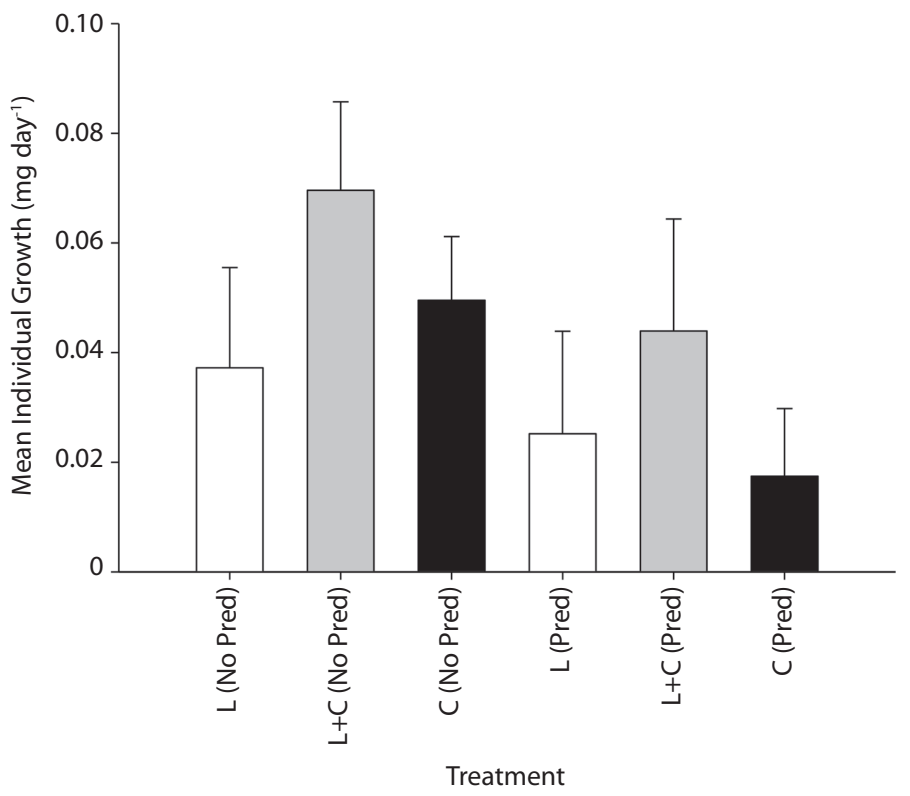

Fig. 3. Mean individual growth rate (mg per day) of Leptophlebiidae nymphs in resource treatments $(\mathrm{L}=\mathrm{leaf}, \mathrm{C}=\mathrm{cobble}$, $\mathrm{L}+\mathrm{C}=$ leaf + cobble) in the presence (Pred) or absence (No Pred) of omnivorous shrimp (X. elongata). Error bars are $1 \pm$ Standard error.

TABLE 2

Analysis of Variance (ANOVA) results for mayfly growth experiments.

\begin{tabular}{lccccc}
\multicolumn{1}{c}{ Classes } & d.f. & Type III S.S. & Mean Square & F Value & $p$ value \\
Predator & 1 & 0.007 & 0.0073 & 3.30 & 0.08 \\
Treatment & 2 & 0.007 & 0.0035 & 1.63 & 0.21 \\
Interaction & 2 & 0.001 & 0.0004 & 0.21 & 0.81 \\
\hline
\end{tabular}

Classes are testing for the effects of Predator (presence, absence), Treatment (leaf, cobble, leaf + cobble), and the Interactive effect of both classes (Predator x Treatment) on mayfly growth rates. A total of 18 replicates (e.g., growth estimates) per treatment were included in the model $(n=54)$. Estimates for the "no-resource" treatment $(n=18)$ were removed prior to analysis as these resulted in zero growth.

absent altogether. This observation suggests that introducing a predator with the cobble substrate does not affect the mayfly's preference for this substrate perhaps indicating that the smaller consumer would risk the chance of predation. Our results also suggest that there may be a greater preference for the cobble as an optimal resource even with the option of a leaf alternative.

Our findings are supported by similar studies of stream taxa in northeastern Puerto Rico and in ecosystems in temperate regions. For example, a study observing the colonization, distribution, and immigration of Baetis bicaudatus on rock substrates describes greater densities of B. bicaudatus on substrates with high periphyton densities as compared with densities on substrates with lower periphyton densities (Richards \& Minshall, 1988). Also, a previous study has alluded to the potential for smaller consumers to benefit from the presence of shrimps through potential resource facilitation (Ramírez \& Hernández-Cruz, 2004). Also, our results suggest that some aquatic insects, such as leptophlebiid mayflies, may partition resources effectively with shrimp and the absence of 
TABLE 3

Analysis of Variance (ANOVA) results for mayfly growth experiments.

\begin{tabular}{lccccc}
\multicolumn{1}{c}{ Classes } & d.f. & Type III S.S. & Mean Square & F Value & P value \\
Predator & 1 & 0.007 & 0.0072 & 3.40 & 0.07 \\
Treatment & 2 & 0.007 & 0.0035 & 1.66 & 0.20 \\
\hline
\end{tabular}

Symbols as in Table 2 .

macroconsumers may not reflect any potential increases in overall fitness (e.g., growth).

In addition, a previous patch choice experiment with Baetis tricaudatus mayfly nymphs showed that a majority of time was spent in safe, high food patches when provided with simultaneous access to feeding patches under different predation risks and food abundance. Consequently, fewer periods of time were spent in safe, low food patches, risky, high-food patches and risky, low food patches, respectively (Scrimgeour, Culp \& Wrona, 1994; Scrimgeour \& Culp, 1994). Furthermore, Peckarsky and McIntosh (1998) found that when Baetis bicaudatus is subjected to various predator cues they increased drift dispersal and suppressed night-time feeding. Although these studies provide insight on the foraging behavior of a functionally similar (i.e., grazing) mayfly in the presence of a strict predator, the effects of an omnivorous macroconsumer which can influence other taxa as both a competitor and predator are still vague.

Interspecific interactions with omnivorous macroconsumers in these ecosystems could tend to favor direct (e.g., predation) and indirect (e.g., competition effects), thus excluding smaller taxa from preferable habitats and resources. For example, X. elongata has been observed to have a prey preference on larger mayflies over relatively smaller chironomids (Crowl et al., 2000), although detritus appeared to make up a large proportion of diet in field experiments (Crowl et al., 2001). In addition, a study by Ramirez \& Hernandez-Cruz (2004) comparing streams in this region with different assemblages of omnivorous shrimps showed that high shrimp densities yielded decreased abundance, biomass and species richness of aquatic insect taxa. However, leptophlebiid mayflies in the Ramírez \& Hernández-Cruz (2004) study yielded higher habitat-specific abundance and biomass in streams with higher shrimp densities. These results support the possibility that $X$. elongata could play a major role in influencing leptophlebiid mayfly resource and habitat preference through direct predation, but also influence this group through interspecific competition and resource facilitation.

Although our results from the growth experiment did not indicate any potential fitness benefits from choosing a different substrate resource, there was a trend for increased growth when both resources where present. Other studies have shown heterogeneity of habitats to be positively correlated with increases in abundance, biomass and even diversity of both consumers and producer communities (Palmer \& Poff, 1997; Poff \& Nelson-Baker, 1997). Perhaps such heterogeneity not only allowed for shelter and increased protection from predators, but also provided the availability of a diverse food resource when the preferred item presented an increased probability of predator encounter. These conditions are further supported by the continuous mortality of mayfly nymphs in the absence of either resource throughout our study.

Our results also present a growing conservation issue regarding the loss of migratory taxa (e.g., many shrimps, snails and fishes) in these tropical island stream ecosystems. In the last decade, much controversy has been debated in Puerto Rico regarding the impact of standing dams as they inhibit the upstream migration of amphidromous taxa (Benstead, March, Pringle \& Scatena, 1999; Pringle, 2000; March, Benstead, Pringle \& Scatena, 2003; 
Hein et al., 2011). It has been suggested that these barriers not only result in different biotic communities, but may also have an impact on ecosystem processes. For example, shrimps have been shown to play an important role in leaf litter breakdown, particulate organic matter exports (e.g., seston) and controlling benthic algal communities (Pringle et al., 1993; Pringle, 1996; Cross et al., 2008). Thus, a loss of shrimp from an upstream ecosystem could perhaps trigger an increase of other consumers (e.g., insects) (Crowl et al., 2001; March, Benstead, Pringle \& Ruebel, 2001; Bobeldyk \& Ramírez, 2007). However, tropical ecosystems are highly variable and hard to predict. Organic matter dynamics among streams with differing shrimp densities may suggest a shift in ecosystem function (Crowl et al., 2002; Cross et al., 2008). Ongoing studies assessing macroinvertebrate community structure and interspecific interactions in relation to organic matter (e.g., resource) budgets will further explore the role of benthic consumers in these ecosystems.

\section{ACKNOWLEDGMENTS}

This study was in part funded by a Research Experiences for Undergraduates Summer Internship in Ecology and Evolution awarded to N. Macias (National Science Foundation Division of Biological Infrastructure-0552567 to A. Ramírez) and by a Minority Postdoctoral Research Fellowship awarded to C. Colón-Gaud (NSF DBI-0905345). All work was sponsored through the Institute for Tropical Ecosystem Studies at the University of Puerto Rico, Río Piedras Campus and the El Verde Field Station in the LUQ LTER. Additional support was provided through the Science Educational Equity Program at California State University Sacramento. Diana Martino, Keysa Rosas, Gus Engman, T.T. Sprinkles and Pedro Torres assisted with field collections, laboratory experiments, and manuscript drafts. The El Verde staff and Summer 2010 REU participants provided additional support and commentary.

\section{RESUMEN}

Las relaciones interespecíficas pueden jugar un papel importante en la determinación del uso de recursos y selección de hábitat entre especies que compiten. Hemos examinado las interacciones entre un camarón omnívoro y un efemeróptero que se alimenta de vegetación, dos taxones codominantes en las partes altas de arroyos de Puerto Rico, para evaluar el efecto de los depredadores en el uso de recursos del efemeróptero y el crecimiento instantáneo en un ecosistema de selva tropical. Examinamos experimentalmente el efecto del camarón Xiphocaris elongata sobre la tasa de crecimiento y selección de recursos en ninfas efemerópteras (Leptophlebiidae). Hicimos experimentos de laboratorio de 5 días, dando a los efemerópteros acceso a dos opciones de sustrato (piedrecillas u hojas) en presencia o ausencia del camarón. Para evaluar los efectos sobre el crecimiento probamos cuatro tratamientos (piedrecillas, hojas , piedrecillas + hojas, sin ambas), en presencia o ausencia del camarón. Los efemerópteros prefirieron las piedrecillas a las hojas $(\mathrm{p}<0,05)$ independientemente de la presencia de los camarones. Esta preferencia fue mayor cuando junto a las hojas había camarones. Los camarones no afectaron el crecimiento de los efemerópteros $(\mathrm{p}=$ 0,07). Las ninfas efemerópteras crecieron mejor sin camarones y en acuarios con piedrecillas y hojas. Nuestros resultados sugieren que las interacciones interespecíficas entre estos animales podrían influir en la dinámica de la materia orgánica (por ejemplo, procesamiento de la hojarasca y su exportación) en los arroyos puertoriqueños.

Palabras clave: interacciones interespecíficas , depredador-presa, camarones, efemerópteros, corrientes tropicales.

\section{REFERENCES}

Benke, A. C., Huryn, A. D., Smock, L. A., \& Wallace, J. B. (1999). Length-mass relationships for freshwater macroinvertebrates in North America with particular reference to the southeastern United States. Journal of the North American Benthological Society, 18, 308-343.

Benke, A. C., \& Huryn, A. D. (2006). Secondary production of macroinvertebrates. In F.R. Hauer \& G.A. Lamberti (Eds.), Methods in Stream Ecology, $2^{\text {nd }}$ ed. (pp. 691-710). San Diego: Academic Press.

Benstead, J. P., March, J. G., Pringle, C. M., \& Scatena, F. N. (1999) Effects of a low-head dam and water abstraction on migratory tropical stream biota. Ecological Applications, 9, 656-668.

Bobeldyk, A. M., \& Ramírez, A. (2007). Leaf breakdown in a tropical headwater stream (Puerto Rico): The role of freshwater shrimp and detritivorous insects. Journal of Freshwater Ecology, 22, 581-590. 
Connell, J. H. (1983). On the prevalence and relative importance of interspecific competition: evidence from field experiments. The American Naturalist, $122,661-696$.

Covich, A. P., Crowl, T. A., Johnson, S. L., Varza, D., \& Certain, D. L. (1991). Post-Hurricane Hugo increases in atyid shrimp abundances in a Puerto Rican montane stream. Biotropica, 23, 448-454.

Covich, A. P., \& McDowell, W. H. (1996). The stream community. In D. P. Reagan \& R. B. Waide (Eds.), The Food Web of a Tropical Rainforest (pp. 433-459). Chicago: University of Chicago Press.

Covich, A. P., Crowl, T. A., Johnson, S. L., \& Pyron, M. (1996). Distribution and abundance of tropical freshwater shrimp along a stream corridor: response to disturbance. Biotropica, 28, 484-492.

Covich, A. P., Crowl, T. A., Hein C. L., Townsend M. J., \& McDowell W. H. (2009). Predator-prey interactions in river networks: comparing shrimp spatial refugia in two drainage basins. Freshwater Biology, 54, 450-465.

Cowan, C. A., \& Peckarsky, B. L. (1994). Diel feeding and positioning periodicity of a grazing mayfly in a trout stream and a fishless stream. Canadian Journal of Fisheries and Aquatic Sciences, 51, 450-459.

Cross, W. F., Covich, A. P., Crowl, T. A., Benstead, J. P., \& Ramirez, A. (2008). Secondary production, longevity and resource consumption rates of freshwater shrimps in two tropical streams with contrasting geomorphology and food web structure. Freshwater Biology, 53, 2504-2519.

Crowl, T. A, Bouwes, N., Townsend, M. J., Covich, A. P., \& Scatena, F. N. (2000). Estimating the potential role of freshwater shrimp on an aquatic insect assemblage in a tropical headwater stream: a bioenergetics model. Verhandlungen der Internationalen Vereinigung fur Theorestische und Angewandte Limnologic, 27, 1-5.

Crowl, T. A., McDowell, W. H., Covich, A. P., \& Johnson, S. L. (2001). Freshwater shrimp effects on detrital processing and nutrients in a tropical headwater stream. Ecology, 82, 775-783.

Crowl, T. A., Covich, A. P., Scatena, F. N., Phillips, R., Townsend, M. J., \& Vinson, D. K. (2002). Particulate organic matter dynamics in tropical headwater streams: A comparison of biotic and abiotic factors. Verhandlungen der Internationalen Vereinigung fur Theorestische und Angewandte Limnologic, 28, 1-5.

Crowl, T. A., Welsh, V., Heartsill-Scalley, T., \& Covich, A. P. (2006). Effects of different types of conditioning on rates of leaf-litter shredding by Xiphocaris elongata, a Neotropical freshwater shrimp. Journal of the North American Benthological Society, 25, 198-208.

Culp, J. M., Glozier, N. E., \& Scrimgeour, G. J. (1991). Reduction of predation risk under the cover of darkness: avoidance responses of mayfly larvae to a benthic fish. Oecologia, 86, 163-169.

Culp, J. M., \& Scrimgeour, G. J. (1993). Size dependent diel foraging periodicity of a mayfly grazer in streams with and without fish. Oikos, 68, 242-250.

Hein, C. L., Pike, A. S., Blanco, J. F., Covich, A. P., Scatena, F. N., Hawkins, C. P., \& Crowl, T. A. (2011). Effects of coupled natural and anthropogenic factors on the community structure of diadromous fish and shrimp species in tropical island streams. Freshwater Biology, 56, 1002-1015.

Kohler, S. L., \& McPeek, M. A. (1989). Predation risk and the foraging behavior of competing stream insects. Ecology, 70, 1811-1825.

March, J. G., Benstead, J. P., Pringle, C. M., \& Ruebel, M. W. (2001). Linking shrimp assemblages with rates of detrital processing along an elevational gradient in a tropical stream. Canadian Journal of Fisheries and Aquatic Sciences, 58, 470-478.

March, J. G., Benstead, J. P., Pringle, C. M., \& Scatena, F. N. (2003). Damming tropic island streams: Problems, solutions, and alternatives. Bioscience, 53, 1069-1078.

McIntosh, A. R., Peckarsky, B. L., \& Taylor, B. W. (1999). Rapid size-specific changes in the drift of Baetis bicaudatus (Ephemeroptera) caused by alterations in fish odour concentration. Oecologia, 118, 256-264.

Palmer, M. A., \& Poff, N. L. (1997). Heterogeneity in streams: The influence of environmental heterogeneity on patterns and processes in streams. Journal of the North American Benthological Society, 16, 169-173.

Pan, W. (2001). Akaike's information criterion in generalized estimating equations. Biometrics, 57, 120-125.

Peckarsky, B. L., \& McIntosh, A. R. (1998). Fitness and community consequences of avoiding multiple predators. Oecologia, 113, 565-576.

Peckarsky, B. L., Taylor, B. W., McIntosh, A. R., McPeek, M. A., \& Lytle, D. A. (2001). Variation in mayfly size at metamorphosis as a developmental response to risk of predation. Ecology, 82, 740-757.

Persson, M., Andersson, S., Baden, S., \& Moksnes, P. O. (2008). Trophic role of the omnivorous grass shrimp Palaemon elegans in a Swedish eelgrass system. Marine Ecology Progress Series, 371, 203-212.

Pescador, M. L., Masteller, E. C., \& Buzby, K. M. (1993). Composition and phenology of Ephemeroptera from tropical rainforest stream at El Verde, Puerto Rico. Journal of Kansas Entomology Society, 66, 151-159.

Poff, N. L., \& Nelson-Baker, K. (1997). Habitat heterogeneity and algal-grazer interactions in streams: Explorations with a spatially explicit model. Journal of the North American Benthological Society, 16, 263-275. 
Posey, M. H., \& Hines, A. H. (1991). Complex predatorprey interactions within an estuarine benthic community. Ecology, 72, 2155-2169.

Pringle, C. M., Blake, G. A., Covich, A. P., Buzby, K. M., \& Finley, A. (1993). Effects of omnivorous shrimp in a montane tropical stream: Sediment removal, disturbance of sessile invertebrates and enhancement of understory algal biomass. Oecologia, 93, 1-11.

Pringle, C. M. (1996). Atyid shrimp (Decapoda: Atyidae) influence the spatial heterogeneity of algal communities over different scales in tropical montane streams, Puerto Rico. Freshwater Biology, 35, 125-140.

Pringle, C. M. (2000). Riverine connectivity: Conservation and management implications for remnant natural areas in complex landscapes. Verhandlungen der Internationalen Vereinigung fur Theorestische und Angewandte Limnologic, 27, 1-16.
Ramirez, A., \& Hernandez-Cruz, L. R. (2004). Aquatic insect assemblages in shrimp-dominated tropical streams, Puerto Rico. Biotropica, 36, 259-266.

Richards, C., \& Minshall, G. W. (1988). The influence of periphyton abundance on Baetis bicaudatus distribution and colonization in a small stream. Journal of the North American Benthological Society, 7, 77-86.

Rosenzweig, M. L. (1981). A theory of habitat selection. Ecology, 62, 327-335.

Scrimgeour, G. J., \& Culp, J. M. (1994). Feeding while evading predators by a lotic mayfly: linking shortterm foraging behaviors to long-term fitness consequences. Oecologia, 100, 128-134.

Scrimgeour, G. J., Culp, J. M., \& Wrona, F. J. (1994). Feeding while avoiding predators: evidence for a forager size-specific trade-off by a lotic mayfly. Journal of the North American Benthological Society, 13, 368-378. 
